University of Nebraska - Lincoln

DigitalCommons@University of Nebraska - Lincoln

June 1983

Integration of Social Indicators Into Holistic Geobased Models

F. Gregory Hayden

University of Nebraska - Lincoln, ghayden1@unl.edu

Follow this and additional works at: https://digitalcommons.unl.edu/cbafacpub

Part of the Business Commons

Hayden, F. Gregory, "Integration of Social Indicators Into Holistic Geobased Models" (1983). College of Business Faculty Publications. 28.

https://digitalcommons.unl.edu/cbafacpub/28

This Article is brought to you for free and open access by the Business, College of at DigitalCommons@University of Nebraska - Lincoln. It has been accepted for inclusion in College of Business Faculty Publications by an authorized administrator of DigitalCommons@University of Nebraska - Lincoln. 


\section{Integration of Social Indicators Into Holistic Geobased Models}

\section{F. Gregory Hayden}

No scientific proposition which records the processes and results of observation and experiment is complete unless processes and results are stated in numerical form.

John Dewey

A social indicator may be defined as a statistic of direct normative interest which facilitates concise, comprehensive, and balanced judgments about the condition of major aspects of the society.

Kenneth C. Land

We have seen that life is characterized by a maze of interdependence, yet no framework has emerged for its systematic study. Although specialists and disciplinary generalists have made major gains in understanding this or that part of human life and a few indirect effects here and there, we remain a long way from assembling a single framework for socioenvironmental inquiry.

Marcus Felson

The author is Professor of Economics, University of Nebraska, Lincoln. This article was presented at the Annual Meeting of the Association for Evolutionary Economics, New York City, 28-30 December 1982. 
The current need in social indicator modeling is a general framework for socioenvironmental inquiry. This is consistent with John Dewey's advice on social measurement given more than forty years ago. This article will follow Marcus Felson's advice to develop socioenvironmental accounts based on "map, clock, and calendar." This can be accomplished by combining the social fabric matrix with temporal sequencing and geobased data systems.

\section{Evolution of the Concern for Social Accountability}

Early in this century, Thorstein Veblen indicated that we should model societal inquiry to determnie whether a societal system is servicable. Veblen's analysis was unrefined, in a scientific sense, but his intention initiated a new mode of analysis and new measurement concerns. John M. Clark emphasized that social scientists must escape their market mentality in order to develop social measurement: "Even if one tries to limit the inquiry ... by accepting people's existing ideas of what they want, there remain questions of balancing values and costs which cannot be resolved by appeal to valuations established in markets .... One must look outside of markets to complete one's picture of the evidence of people's actual valuations." Steven Hickerson, in his summary of Clark's social thought, says that the "components of Clark's economics, then, give rise to the emphasis on social values, therefore, his call for the development of a social value theory independent of market valuations." ${ }^{3}$ In Clark's view, "the need for a system of social accounting stems not so much from a rejection of the simple market performance (profit) criterion as it does from the recognition that the narrow financial accounting founded on that criterion is grossly incomplete." 4

\section{Holistic Data Systems}

In conjunction with the dissolution of the pecuniary ideology was the dissolution of the belief that social systems could be understood through the "atomistic" behavior of the individual elements. The holistic view of social science required an alternative approach to measurement, articulated by John Dewey.

Dewey's advice regarding measurement has particular meaning for social indicators. (1) They must be consistent with the needs of the social problem being pursued. ${ }^{5}$ Social data should not be recycled data collected for other purposes. (2) They are not all in numerical form. ${ }^{6}$ (3) Mere separation of discrete objects is not the basis of numerical identity. ${ }^{7}$ Quan- 
tification should be designed to express a system. (4) Aggregation of discrete objects is "not a case of measuring but mere counting." Until a system is defined, quantification leads to indeterminate aggregates. ${ }^{9}$ (5) Social measurement must be relative and limiting: relative to the system and expressing the limits required by all systems. ${ }^{10}(6)$ Systems principles of arrangement and order should guide numerical expression. Thus the data system should be designed to articulate patterns, sequences, ordering, and linkages. ${ }^{11}$ (7) It is important to remember that in reality systems are not disintegrated. Environmental conditions, institutions, and organisms exist only as a synthetic whole. ${ }^{12}$ (8) System specification must include physical laws and their interactions along with technology. ${ }^{13}$ (9) It must also include conditions like soil, sea, mountains, and climate, the environment in general. ${ }^{14}$ Thus, a social indicator system should be a geobased data system. There has not been a new paradigm for social measurement since Dewey's work, although the social indicator movement has elaborated and applied it a good deal.

\section{So What are Social Indicators?}

The early years of the social indicator movement in the mid-1960s concentrated on "output" indicators. Following the lead of policy scientist Yehezkel Dror, social indicators were designed to serve as secondary criteria (operational objectives or instrumental values) for the more primary criteria (social goals or terminal values) ${ }^{15}$ These indicators included measures of the volume of public goods and services, the quality of public services, and comparison indicators. The emphasis was on program results rather than program content or budget size.

For example, a society with a cultural value of dynamic individual action will have a policy goal for good health. To assess public health programs, it is necessary to establish operational measures such as the number of hospital beds per thousand of population, or the change in the disease level. For every terminal value numerous indicators are needed to determine whether subsidiary beliefs are being fulfilled-in this example, beliefs about what makes for good health.

It is crucial that the indicator be consistent with the primary goal because operationally the indicator becomes the decision criterion. It is possible conceptually to distinguish between primary and secondary criteria, but operationally it is not. A primary goal of, let's say, an efficient engine differs greatly in reality depending on whether one uses a horsepower or pollution indicator, and educational equity differs greatly depending on whether one uses an expenditure per student or a standardized 
test score as the indicator. In reality the social indicators determine the primary criteria.

It quickly became apparent in the 1960s that more than "output" is involved in delivering the correct social results. Thinking only of input from and output to an external world was consistent with the narrow view of a factory manager. However, as Dewey emphasized, ends and means cannot be separated and neither can "inputs" and "outputs." Secondly, in a social system, there is no external realm except as established by the scientific investigator. What our categories of concern are depends on the way we view the problem. So instead of thinking of input and final output, the policy scientist should think of processes and consequences-consequences of alternative processes.

The indicator concern today extends to system measures instead of just elements and consequences. The indicator interest is with any set of data that assists in transforming resources and social organization into instrumental results. So in addition to output indicators we also need linkage indicators, statistical verification, regression coefficients between the elemental variables, and so forth. The indicators can be categorized as follows:16 (1) Consequence or impact indicators, which are designed to measure the results of policies or the processes of social institutions; (2) requirement indicators, which measure the required elements or components as defined by the working rules of going concerns or social processes; (3) relationship indicators, which measure the congruency among the elements and components; and (4) monitoring indicators, which are selected to provide information on some part of the system, especially after policy initiations.

\section{Unity Through the Social Fabric Matrix}

What is needed is a framework for organizing those categories into a unified data system in a manner that will provide a transdependent model for articulating social systems with a concomitant geobased component. The social fabric matrix that was explained in the September 1982 issue of this journal can serve that purpose. ${ }^{17}$

To a great extent those concerned with social indicators have not integrated geobased data; yet it is crucial. Many social and environmental problems are a result of an inappropriate location of the social delivery rather than the delivery itself. In addition, one aspect lacking in geobased data systems is the explanation of social delivery. Some very useful socioeconomic mapping exists; some of it is updated regularly for establishing trends, and some of it is structured to allow for geosocial analysis. The 
statistics to be input in a list format and projected onto area-type socioeconomic data planes. ${ }^{22}$ What is offered below is a way to tie together the socioeconomic data as compiled by the Denver study and a data system explaining its delivery in those areas. This will allow us to move from reporting magnitudes such as housing and income to explaining the geosocial system providing the magnitudes.

\section{Defining the Cells in the Social Fabric Matrix}

The social fabric matrix allows for the entities of concern in social data systems-beliefs, values, industrial production, legal decisions-and provides a framework for integrating them. The matrix can then be converted to a boolean matrix and displayed as a digraph (Figure 2). The data needed in each cell of the matrix is displayed in Figure 1.

\begin{tabular}{|r|l|l|}
\hline 1 & What is delivered & $\mathrm{SI}_{1}$ \\
\hline 2 & Level of delivery & $\mathrm{SI}_{2}$ \\
\hline 3 & $\begin{array}{l}\text { Geographic location } \\
\text { of delivery }\end{array}$ & $\mathrm{SI}_{3}$ \\
\hline 4 & Time of delivery & $\mathrm{SI}_{4}$ \\
\hline 5 & $\begin{array}{l}\text { Appropriative rule } \\
\text { for delivery }\end{array}$ & $\mathrm{SI}_{5}$ \\
\hline
\end{tabular}

SI $_{i}=$ Set of social indicators

Figure 1. Indicators Needed in Social Fabric Matrix Cells

\section{Temporal Sequencing}

For the purpose here, we emphasize the locational aspect of the cell. However, in order to complete a digraph sequence from the matrix that corresponds to a temporal sequence, it is necessary to show the time of delivery for each cell. The concern here is not with the correct social time, for that will change with the problematic situation. ${ }^{23}$ The concern is to emphasize the need for temporal ordering so as to be able to determine simultaneous flows and actions. The temporal scale is displayed on the bottom of Figure 2 .

\section{Boolean Digraphs with Geobased Information}

The social fabric matrix, after its conversion to a boolean matrix, can be converted to a sequence digraph as was explained in the December 
1982 issue of this journal. ${ }^{24}$ If the spatial factor is explicitly included, then the digraph for defining the social system and for organizing social data can be displayed as in Figure 2, or on a computer digitized map itself. The lines (edges) are the entities that the components (vertices) are delivering to other components.

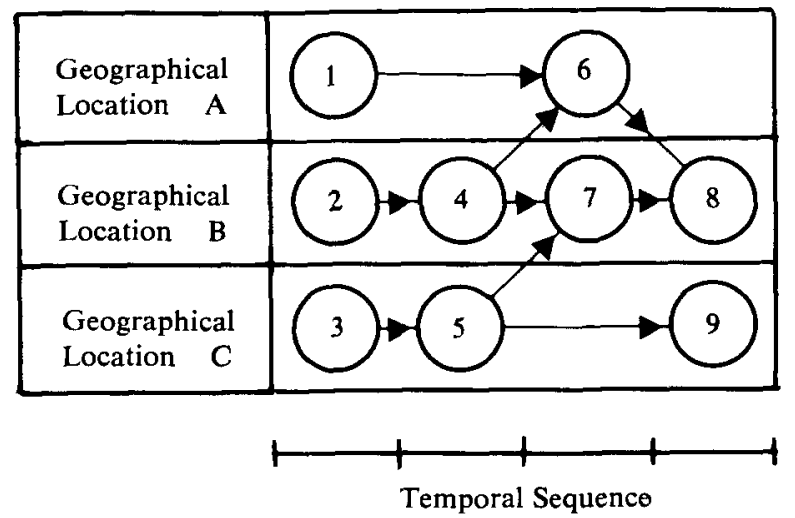

1, 2, and $3=$ Legal Codes; 4,5 , and $6=$ Factories; $7=$ Waste Disposal; 8 and $9=$ Consumers

Figure 2. Geobased Delivery Digraph

Figure 2 is different from the usual sequence digraph because it requires that the digraph be location-explicit so that the geobased information becomes explicit.

There are numerous advantages to this approach for structuring a social data system. First, no information is in the geosocial system that cannot be related to other connections and components in the social process. Second, to define the operation of each component, let's say a factory, requires defining the elements of the components, and the components delivering the elements. If social policy makers were more cognizant of the origin of delivery, they might change their policies that suggest delivery whose production is extremely harmful—such as Lester Thurow's suggestion that the United States emphasize agricultural exports in spite of the tremendous environmental and community damage that that production entails.

Third, it immediately becomes apparent that no monetary or any other single indicator, or dozen of indicators for that matter, is adequate to articulate a social system. Fourth, this approach emphasizes spatial delivery. For example, in Figure 2, component 5 could be delivering record albums to one component at one location and delivering polychlorinated biphenyl (PCB) substances to component 9 at another location. (If the indicator 
base of the production process is monetary, the level of PCBs, although they are the most important information about the recording industry, would be ignored.)

Fifth, the delivery by location becomes especially important for monitoring environmental systems to see whether geographical and environmental characteristics are consistent with the delivery of the social system. For example, the delivery of high horsepower tractors and center pivot irrigation systems to arid regions of sandy soil with little organic matter, such as the Sandhills of Nebraska, destroys the soil's organic matter and causes severe soil erosion. Soil and climate mapping can connect technological zoning with the production process, and help complete indicative plans for telling producers what kinds of equipment they need. As another example, if we can map the major sources of oxygen and we find, as claimed by some, that 50 percent of the world's oxygen supply comes from the Amazon area, and if we trace the use of recent Amazon clearings and find that it is for cattle to be made into MacDonald's hamburgers, then the need for oxygen zoning becomes obvious.

Sixth, in addition to protecting environmental resources, it can also be used to keep people out of hazardous locations, if they are properly mapped. There are currently three thousand hazardous waste dumps in the United States designated by the Reagan administration as serious. To have those mapped in a manner so that the social process is prevented from delivering people, animals, or products to them is critical. For example, children in Missouri and Arkansas have recently been delivered to areas contaminated with dioxin at levels higher than at Love Canal. The dioxin-contaminated areas should be mapped and the data transmitted to the computer terminals of social and corporate agencies that may be delivering children to such locations. The way to identify such agencies is through a social system articulation that indicates the linkages. The concern exists, the knowledge exists; the innovation of the geosocial information system is what is lacking.

Seventh, obviously adding the spatial dimension to the system of social indicators provides information for transportation planning. As Allan Gruchy has emphasized, any plan for the development of New York City should take into account the domestic and international needs of the United States as a major exporting and importing country. One ingredient there is the transportation system needed for the exports and imports.

Eighth, the geobased approach also can show the demise of components located in New York City if the traffic flow is diminished. For example, let's assume a decision is made to direct imports that had entered the country through New York harbors to enter elsewhere. A geobased social 
information system will indicate what components must be transferred to the new location, and thereby indicate the kind of transfer assistance that should be included in the policy.

Ninth, it will become possible to see the impact of changes in attitudes, beliefs, and codes as we move across the landscape from community to community. If we assume that components 1,2 , and 3 in Figure 2 are different legal codes regulating pollution, then we can expect to find different kinds of industry in a location because of the codes and also differently patterned digraphs. Or, we could look at codes regulating milk delivery, for example, to determine why milk delivery is localized while meat delivery is not. This kind of information system will allow us to evaluate the effectiveness of a code. It will also allow for attitude and belief mapping that can be used to show the geographical effect of different beliefs on social institutions and on the environment.

Tenth, using the social fabric matrix to establish a geobased data system will allow us to identify linkages and connections among communities, regions, and global systems. Communities are the clustering of component relationships in a spatial setting. A region differs from a community in the flow and linkages between its components.

Eleventh, this kind of data system will also allow for the continued expansion of statistical analysis as information is organized in a new manner, as well as require the development of new statistical techniques.

Last, it will also allow boolean algebra, graph theory, and network analysis to expand their applicability to geosocial systems. A digraph (directed graph) as is represented in Figure 2 makes explicit relationships among objects. Once established, numerous system characteristics can be calculated: for example, the degree of connectedness, the redundancy of the edges, the relative distance of the various delivery flows, pattern comparisons, the degree of isomorphism in the graph structure, and the degree of diffusion. ${ }^{25}$ The mathematics of graph theory has found some realworld applications in both sociology and geography. The social indicator system recommended here should allow its greater utilization.

\section{Notes}

1. Marcus Felson, "Social Accounts Based on Map, Clock, and Calendar," Social Accounting Systems, ed. F. Thomas Juster and Kenneth C. Land (New York: Academic Press, 1981), p. 219.

2. John M. Clark, Economic Institutions and Human Welfare (New York: Farrar and Rinehart, 1957), p. 114.

3. Steven Hickerson, "John Maurice Clark's View of Social Valuation and 
Accounting: Potential Applications of Policy Assessment Techniques," Review of Social Economy 39 (December 1981) : 289-305.

4. Ibid., p. 294.

5. John Dewey, Logic: The Theory of Inquiry (New York: Henry Holt and Company, 1938), pp. 200, 205, 211, and 499.

6. Ibid., p. 205.

7. Ibid., p. 211.

8. Ibid.

9. Ibid., p. 209.

10. Ibid., p. 212.

11. Ibid., pp. 209-10.

12. Ibid., p. 34.

13. Ibid., p. 492.

14. Ibid., pp. 33 and 492.

15. See Yehezkel Dror, Public Policymaking Reeaxmined (Scranton, Penn.: Chandler, 1968).

16. Adapted from Hickerson, "Clark's View," pp. 303-304.

17. F. Gregory Hayden, "Social Fabric Matrix: From Perspective to Analytical Tool," Journal of Economic Issues 16 (September 1982) : 637-62.

18. United States Department of Agriculture Soil Conservation Service, National Resources Investory, 1982 (In process of completion and publication ), P.O. Box 2890, Washington, D.C. 20013.

19. William H. Anderson, "Overview of the Landsat System," Identifying Irrigated Lands Using Remote Sensing Techniques: State of the Art (symposium proceeding), (Sioux Falls, S.D.: Earth Resources Observation Systems Program, U.S. Geological Survey, 1979), p. 2. See also: Benjamin F. Richardson, Jr., ed., Introduction to Remote Sensing of the Environment (Dubuque, Iowa: Kendall/Hunt, 1978).

20. Gary E. Johnson, "The Columbia River and Tributaries Irrigation Withdrawals Analysis Project: Feasibility Analysis and Future Plans," in Anderson, Identifying Irrigated Lands, p. 43.

21. Craig Tom, Lee D. Miller, and Jerrold W. Christenson, Spatial Land-Use Inventory, Modeling, and Projection/Denver Metropolitan Area with Inputs from Existing Maps, Airphotos, and Landsat Imagery, NASA Technical Memorandum 79710 (Greenbelt, Maryland: Goddard Space Flight Center, 1978), p. 11.

22. Ibid., pp. 17-26 and 54-55.

23. See F. Gregory Hayden, "Project Evaluation in a Futures Real Time System," Journal of Economic Issues 16 (June 1982): 402-12; and Don Parkes and W. D. Wallis, "Graph Theory and the Study of Activity Structure," in Human Activity and Time Geography, ed. Tommy Corlstein, Don Parkes, and Nigel Thrift (New York: John Wiley \& Sons, 1978), pp. 76-77.

24. F. Gregory Hayden, "Organizing Policy Research Through the Social Fabric Matrix,"Journal of Economic Issues 16 (December 1982) : 101326.

25. See Parkes and Wallis, "Graph Theory," pp. 80-98; and James S. Coleman, Introduction to Mathematical Sociology (London: Free Press, 1976). 